\title{
The Recreational Reading of University of Illinois Students
}

Mr. Chapin is in the circulation department, University of Illinois Library.

$\mathrm{T}$

HIS Is a summary of library school student investigations to determine the recreational reading habits of University of Illinois students. Three different studies were made on this problem in the spring of 1949. One study was concerned with the reading habits of a sample group of university students, the second study was of a sample of student patrons of the library, and the third was a content analysis of the materials most often reported in the first two studies.

The first study used a stratified sample. From the registrar's office, data covering the number and sex of students in each class were obtained, and a sample of 100 names were drawn at random from the pages of the student directory to match these over-all figures (see Table I). From the registrar's office it was found that 53 per cent of the student body were veterans; 52 per cent of

Table I

Composition of Sample of University Students Interviewed

\begin{tabular}{l||c|c|c}
\hline \hline & $\begin{array}{c}\text { Men } \\
\text { (Per cent) }\end{array}$ & $\begin{array}{c}\text { Women } \\
\text { (Per cent) }\end{array}$ & $\begin{array}{c}\text { Total } \\
\text { (Per cent) }\end{array}$ \\
\cline { 1 - 2 } Freshmen & II & 5 & I6 \\
Sophomores & I0 & 4 & 14 \\
Juniors & 23 & 5 & 28 \\
Seniors & 20 & 4 & 24 \\
Miscellaneous & 3 & - & 3 \\
Graduates & I2 & 3 & 15 \\
\hline \multicolumn{1}{|c|}{ Total } & 79 & 21 & I00 \\
\hline
\end{tabular}

the sample were likewise veterans.

A brief interview schedule ( 19 items) was used, and most of the interviews were obtained over the phone. This is not ideal, but was the only practical method available because of the difficulty of finding students at home. The results would probably not be substantially changed had personal interviews been secured in all cases.

Recreational reading was defined for this study as all reading, including magazines, papers and books, but excluding classroom assignments. Fifty-two per cent of the students read for recreation less than four hours per week, and 48 per cent read for recreation more than four hours a week. There was no difference in the amount of time devoted to recreational reading by men and women students, or by married or single students.

The student's year in school, however, is a contributing factor to the amount of time spent on recreational reading (see Table II). Notice that in the group which read more than four hours a week, there are more than twice as many seniors as freshmen. This increase in the amount of recreational reading starts with the sophomore year and mounts steadily throughout college. When the war veteran students are compared with nonveterans, still another variable was found. Forty-five per cent of the veterans read less than four hours a week, compared to 60 per cent of the nonveterans; 55 per cent of the veterans read more than four hours a week, compared to only 40 per cent of the nonveterans. This is prob- 
Table II

Time Spent on Recreational Reading: Comparison by College Class

\begin{tabular}{c||c|c|c|c|c}
\hline \hline Hours Per Week & $\begin{array}{c}\text { Freshmen } \\
\text { (Per cent) }\end{array}$ & $\begin{array}{c}\text { Sophomores } \\
\text { (Per cent) }\end{array}$ & $\begin{array}{c}\text { Juniors } \\
\text { (Per cent) }\end{array}$ & $\begin{array}{c}\text { Seniors } \\
\text { (Per cent) }\end{array}$ & $\begin{array}{c}\text { Graduates } \\
\text { (Per cent) }\end{array}$ \\
\cline { 1 - 3 } Less than four & 70 & 57 & 54 & 37 & 37 \\
More than four & 30 & 43 & 46 & 63 & 63 \\
\hline
\end{tabular}

ably because the veterans are the morel mature students, and they are the upper-1 classmen. A third variable was uncovered. when we compared the time spent on reading by students engaged in outside activities (including extracurricular work and jobs) with those not so occupied. Thirty-two per cent of the former and 69 per cent of the latter read less than four hours a week; 68 per cent of the former and 31 per cent of the latter read more than four hours a week.

The second study used a questionnaire (of II items) which was distributed in the library on two consecutive days. A total of 400 questionnaires were filled out by students at such points as the circulation desk, the reserve book rooms and the browsing room. Since the distribution of questionnaire returns, by class and sex, was almost the same for the two days, the following analysis rests on the 200 questionnaire returns of one day. There was a similarity between the results of this study and the previous one on the amount of time spent on recreational reading. Both showed that the number of books, magazines and newspapers read regularly does not vary with the sex of the reader.

It was found in this second study that two thirds of the students read one or less books a month outside of class assignments. The remaining one third of the student population reads from two to five books per month. The average of four hours a week spent on recreational reading was consumed mainly by reading magazines and newspapers. Two or more magazines were read each week by 62 per cent of the students; 65 per cent read two or more newspapers each day (including the student newspaper).

The third study was concerned with an analysis of the book and magazine titles reported most often in the two earlier studies. Out of the total of 287 books reported as read, 6I per cent of the books were fiction, and 39 per cent nonfiction. Of the nonfiction, the most popular classes were literature, history, travel and biography. Flesch's readability test was applied only to those books reported as read by two or more people in the same survey. The books tested and their scores are given in Table III.

Table III

The Flesch Readability Test As Applied to Certain Book Titles

\begin{tabular}{|c|c|}
\hline Title and Author & $\begin{array}{l}\text { Difficulty } \\
\text { Level }\end{array}$ \\
\hline $\begin{array}{l}\text { Gathering Storm, Chu rchill } \\
\text { Great Rehearsal, Van Doren } \\
\text { Road to Survival, Vogt } \\
\text { Way of All Flesh, Butler } \\
\text { Crusade in Europe, Eisenhower } \\
\text { Inside U.S.A., Gunther } \\
\text { Autobiography, William Allen White } \\
\text { Cheaper by the Dozen, Gilbreth } \\
\text { Pride and Prejudice, Austen } \\
\text { Mister Roberts, Heggen } \\
\text { The Robe, Douglas } \\
\text { Peace of Mind, Liebman }\end{array}$ & $\begin{array}{l}\text { very difficult } \\
\text { difficult } \\
\text { difficult } \\
\text { difficult } \\
\text { fairly difficult } \\
\text { fairly difficult } \\
\text { standard } \\
\text { standard } \\
\text { standard } \\
\text { fairly easy } \\
\text { fairly easy } \\
\text { easy }\end{array}$ \\
\hline
\end{tabular}

Of the magazines read by the students, the general magazines such as Saturday Evening Post, Collier's, New Yorker, etc., are the most widely read group. Running a close second are the pictorial and news magazines. Following in relative order after these big three groups are the digests, science, 
education, business, commerce and other magazines. Life was read by 35 per cent of the students, Time by 29 per cent, Saturday Evening Post by 2 I per cent, Reader's Digest by 14 per cent, Newsweek by 12 per cent, Collier's by 8 per cent, and Look by 6 per cent. None of these magazines have a Flesch score above "standard" and four are below. Six magazines were selected at random from the long list of those mentioned only once (viz., Better Homes and Gardens, Successful Farming, Glamour, Mademoiselle, Christian Century, Farm and Home Science). When the Flesch score was calculated for these magazines all but one was found to have a reading level above "standard" and the sixth was at "standard."

In summary, the typical student spends four hours each week on his recreational reading. This includes books, magazines and newspapers but excludes reading assigned in classes. He spends relatively the same amount of time on his reading as his female classmates. He reads neither more nor less than married students. If he is a veteran, chances are that he spends more time on his reading than does the nonveteran. Whether he is a freshman, sophomore, junior, or senior determines to a great degree the amount of reading he does. As he progresses from freshman to senior year, he reads more. Likewise the busy student engaged in outside activities and work reads more than the one who is not so occupied. Chances are two to three that he reads one book or less a month. These same odds hold in that he will read two or more magazines a week, and two or more newspapers daily. Of the books he reads, 6I per cent will be fiction. The leading contenders for his nonfiction reading are history, biography and travel. Most of the books read will have a readability level classified by Flesch as standard-that is, readable by the average American citizen. $\mathrm{He}$ reads generously among the general, pictorial and news magazines. Chances are one to three that he will read Life magazine every week. No matter what magazine is read, in all probability it will be of a standard or below standard level of difficulty.

\section{Sociology Terminology}

\section{(Continued from page 154)}

uses for such material can be determined from the tracings, and other works may then be sought there. Moreover, investigation in the field of literature has shown that there at least the catalog, even when supplemented by the classification, can never hope to rival subject bibliographies in completeness and effectiveness for use. ${ }^{44}$ (4) Get acquainted with the Library of Congress printed list, shelved very close to the catalog. It contains some references not in the card catalog; it shows all entries and references under Social, for example, much

44 Swank, Raynard C. "The Organization of Library Materials for Research in English Literature." Li brary Quarterly, I 5:49-74, January 1945 . faster than one can determine them by checking through the catalog trays; and it saves time and foot-mileage tramping from alcove to alcove. (5) Remember that often no books have yet been written on very new topics, and the periodical indexes are the logical tools to consult first. (6) The catalog in general can exercise no discrimination as to the value of material included, and the user must separate as best he can the good from the mediocre and irrelevant by observing dates of publication, publisher, series or sponsoring body (if any), as well as author, title and contents (if enumerated). 